\title{
Kebijakan Hukum Pidana Mengenai Rehabilitasi Psikososial Korban Tindak Pidana Terorisme Dalam Sistem Peradilan Pidana
}

\author{
Eprina Mawati, Lies Sulistiani, Agus Takariawan \\ eprina18001@unpad.ac.id \\ Program Studi Magister Hukum Universitas Padjadjaran
}

\begin{abstract}
ABSTRAK
Pada dasarnya kebijakan legislatif atau kebijakan perundang-undangan, secara fungsional dapat dilihat sebagai bagian dari perencanaan dan mekanisme penanggulangan kejahatan, bahkan dapat dikatakan sebagai langkah awal. Kebijakan atau upaya penanggulangan kejahatan pada hakikatnya merupakan bagian integral dari upaya perlindungan masyarakat (sosial defence) dan upaya mencapai kesejahteraan masyarakat (sosial welfare). Dalam penelitian ini menggunakan metode penelitian yuridis normatif, yaitu dengan menerapkan peraturan perundangundangan. Perlindungan hak-hak korban tindak pidana, merupakan tanggungjawab negara terhadap korban, tanpa terkecuali. Hal tersebut merupakan bentuk pertanggungjawaban negara atas ketidakmampuannya dalam melindungi masyarakat, sehingga timbul korban. Namun, efektifitas dan ketepatan sasaran serta bentuk perlindungan yang diberikan Pemerintah Indonesia dinilai masih kurang tepat, khususnya korban tindak pidana terorisme.
\end{abstract}

Kata Kunci : Kebijakan Hukum Pidana, Rehabilitasi Psikososial, Sistem Peradilan Pidana

\begin{abstract}
Basically legislative policies or statutory policies, as a whole can be seen as part of planning and overcoming crime, and can even be approved as a first step. Policies or efforts to reduce poverty are essentially an integral part of efforts to protect the community and efforts to achieve community welfare. In this study using normative juridical research methods, namely by applying legislation. Protection of the rights of victims of criminal acts is the responsibility of the state for victims, without exception. This is a form of state accountability for its inability to protect the community, resulting in victims. However, the effectiveness and accuracy of the targets and forms of protection provided by the Government of Indonesia are still inaccurate, specifically for victims of terrorism.
\end{abstract}


Kaywords : Criminal Law Policy, Psychosocial Rehabilitation, Criminal Justice System.

\section{Pendahuluan}

$\begin{array}{rrl}\text { Salah } & \text { satu esensi dari } \\ \text { kemanusian } & \text { adalah } & \text { berkehidupan }\end{array}$
secara sosial (bermasyarakat). Dalam dimensi sosial terdapat unsur saling interaksi dan mempengaruhi, baik yang bersifat positif maupun negatif. Perilaku mempengaruhi secara negatif dapat berupa dalam bentuk pemaksaan, anacaman dan penggunaan kekerasan sebagai terror agar kemauan atau kehendaknya diperhatikan dan diindahkan. Teroris diletakkan kepada seseorang atau kelompok yang melakukan perbuatan terror untuk menakuti dan memengaruhi orang lain, kelompok atau suatu masyarakat agar mengikuti kemauannya. Para teroris ini selanjutnya menghasilkan ideologi dan gerakan serta kejahatan terorisme yang menjalar tidak hanya pada masyarakat modern tetapi juga pada masyarakat tradisional sekalipun sesungguhnya perilaku itu juga ada meskipun dalam bentuk dan modus yang berbeda bahkan dapat dikatakan bahwa sebenarnya kejahatan terosisme berlangsung di setiap bangsa dan lintas peradaban.

Tragedi bom di sari club dan peddy's club kuta legian bali 12 oktober 2002, adalah teror yang layak digolongkan sebagai kejahatan terbesar di Indonesia dari serangkaian teror yang ada. Tragedi itu adalah sebuah bukti nyata bahwa teror adalah aksi yang sangat keji yang tidak memperhitungkan, tidak memperdulikan dan sungguh-sungguh mengabaikan nilai-nilai kemanusian. Manusia yang tidak tahu menahu akan maksud, misi atau tujuan pembuat teror telah menjadi korban tak berdosa (innocent victim). Rakyat yang tidak bedosa hanya menjadi korban kebiadaban manusia yang di menangkan dan disupremasikan aksi teror yang terjadi di legian bali itu mengingatkan publik pada kejadian black tuesday yaitu peristiwa pengeboman yang telah menghancurkan symbol kapitalisme 
negara adikuasa amerika serikat berupa menara world trade center (WTC) dan symbol pertahanan pentagon. Publik global menarik benang merah bahwa tragedi kasus dan kasus (WTC) amerika serikat adalah produk gerakan kelompok terorisme yang bermaksud merusak kedamaian global, menghancurkan nilai-nilai peradaban, dan mendegradasi hak-hak asasi manusia (HAM). Salah satu tugas POLRI adalah menegakkan hukum, khususnya hukum pidana. Penegakan hukum pidana pada sisi teknis terkait dengan pelaksanaan hukum acara pidana yang didalamnya mengatur bagaimana hukum pidana materil dijalankan, termasuk hak-hak tersangka dan korban. ${ }^{1}$

Rehabilitasi Psikososial adalah semua bentuk pelayanan dan bantuan psikologis serta sosial yang ditunjukan untuk membantu meringankan, melindungi, dan memulihkan konsidi

\footnotetext{
${ }^{1}$ Hasil Seminar Hukum Nasional II tentang Hukum Acara Pidana dan Hak-Hak Asasi Manusia, Semarang 28 Februari 1968, Barda Nawawi Arief, 2011, Kumpulan Hasil Seminar Hukum Nasional, Semarang, BP UNDIP, hal, 16-1.
}

fisik, psikologis, sosial, dan spritual korban sehingga mampu menjalankan fungsi sosialnya kembali secara wajar, antara lain LPSK berupaya melakukan peningkatan kuallitas hidup korban dengan melakukan kerja sama dengan instansi terkait yang berwenang berupa bantuan pemenuhan sandang, pangan, papan, bantuan memperoleh pekerjaan, atau bantuan kelangsungan pendidikan.

Pemberian bantuan Rehabilitasi Psikososial dilaksanakan oleh lembaga yang menyelenggarakan urusan bidang perlindungan sanksi dan korban serta dapat bekerjasama dengan instansi/lembaga terkait lembaga perlindungan saksi korban (LPSK) bekerja sama dengan Pemerintah daerah, Filantropi, Lazismu, Kemensos, Kementrian Pendidikan, dan badan usaha milik negara (BUMN). Data korban terorisme dari 400 orang korban terorime mulai tahun 2002 sd 2019 hanya 34 orang yang mendapatkan bantuan rehabilitasi 
psikososial dari 15 provinsi di indonesia. $^{2}$

Salah satu bentuk perlindungan negara terhadap warga negaranya adalah

dengan menggunakan peraturan perundang-undangan untuk membatasi perilaku

warga negara dalam berbuat atau tidak berbuat sesuatu. Perlindungan hukum adalah memberikan pengayoman terhadap hak asasi manusia (HAM) yang dirugikan orang lain dan perlindungan itu diberikan kepada masyarakat agar dapat menikmati semua hak-hak yang diberikan oleh hukum. $^{3}$

Terorisme sebagai kejahatan multi dimensional, seringkali dipandang hanya dari prespektif pelaku, motif tindakan, dan cara penanggulangan. Sangat sedikit sekali terorisme yang ditinjau dari prespektif korban. Minimnya perhatian terhadap korban terorisme merupakan dampak

2 Hasil Wawancara Penulis dengan Susilaningtias, Wakil Ketua LPSK RI, pada tanggal 21 Januari 2020 bertempat di LPSK.

${ }^{3}$ Satjipto Raharjo, IlmuHukum, Bandung, PT.CitraAdityaBakti, 2000, hal 69. dari kelalaian atau ketidakmampuan suatu negara dalam memberikan perlindungan dan pemenuhan hak-hak korban terorisme. ${ }^{4}$

Korban serangan terorisme mengalami fenomena anonimitas, yang mana semua anggota masyarakat dapat menjadi korban terorisme secara acak. Masyarakat yang menjadi korban tindak terorisme, seakan tidak ada yang memperhatikan, bahkan oleh negara sekalipun. Hal tersebut menjadikan korban menjadi subyek yang tidak penting dalam rangkaian tindakan pemberantasan terorisme di Indonesia, karena fokus serta perhatian pemerintah dan para pembuat kebijakan hanya pada pelaku terorisme. ${ }^{5}$

Perlindungan hak-hak korban tindak pidana, merupakan

$4 \quad \mathrm{~Tb}$ Ronny Rahman Nitibaskara, Tegakan Hukum Gunakan Hukum, Jakarta: Penerbit Gramedia Kompas, 2001, hal. 34.

5 Muhammad Alfath, "Korban Sebagai Dampak dari Tindak Pidana Terorisme : Yang Anonim dan Terlupakan", Jurnal Kriminologi Indonesia Vol. II, Agustus 2009, hal.19-30. 
tanggungjawab negara terhadap korban, tanpa terkecuali. Hal tersebut merupakan bentuk pertanggungjawaban negara atas ketidakmampuannya dalam melindungi masyarakat, sehingga timbul korban. Seyogyanya, seluruh korban tindak pidana harus mendapatkan perlindungan dari negara. Namun, efektifitas dan ketepatan sasaran serta bentuk perlindungan yang diberikan pemerintah indonesia dinilai masih kurang tepat. Salah satu korban tindak pidana yang perlu mendapatkan perhatian khusus adalah korban terorisme. Hal tersebut tentu menjadi pertanyaan besar mengenai pengaturan dan kondisi perlindungan hak korban tindak pidana terorisme di Indonesia. Adapun kemudian, perlu diketahui bahwa setiap negara memiliki pengaturan dan kebijakan yang berbeda atas perlindungan hak korban tindak pidana terorisme, khususnya terhadap peraturan yang mengatur dan bentuk perlindungan yang diberikan terhadap korban tindak pidana terorisme, khususnya dalam upaya pemenuhan hak asasi manusia korban tindak pidana terorisme, yang mana akan merujuk pada rekomendasi model perlindungan korban tindak pidana terorisme di Indonesia.

Sehubungan hal tersebut, maka tentunya seorang saksi dan korban perlu mendapatkan perlakuan dan hakhak khusus, karena mengingat keterangan yang disampaikan dapat mengancam keselamatan dirinya sebagai seorang saksi. Tanpa adanya pengaturan yang tegas dan jaminan keamanan bagi seorang saksi, maka seseorang akan merasa takut untuk menjadi seorang saksi. Padahal keberadaan seorang korban dalam mengungkap suatu tindak pidana sangat penting. Seorang korban berhak memperoleh perlindungan atas keamanan pribadinya dari ancaman fisik maupun psikologis dari orang lain, berkenaan dengan kesaksian yang akan, tengah, atau lebih diberikannya atas suatu tindak pidana. Berdasarkan uraian dalam latar belakang diatas, permasalahan dapat diidentifikasi 
sebagai berikut. Bagaimanakah kebijakan hukum pidana terhadap pemenuhan hak rehabilitasi psikososial pada korban tindak pidana terorisme dalam sistem peradilan pidana? Berdasarkan apa yang penulis sampaikan pada latar belakang permasalahan dan identifikasi masalah, penelitian ini mempunyai maksud dan tujuan sebagai berikut Untuk memahami dan menunjukkan kebijakan hukum pidana terhadap pemenuhan hak rehabilitasi psikososial pada korban tindak pidana terorisme dalam sistem peradilan pidana.

\section{B. Hasil Dan Pembahasan}

Istilah kebijakan dalam tulisan ini diambil dari istilah "policy" (inggris) atau "politiek" (belanda). Bertolak dari kedua istilah asing ini, maka istilah "kebijakan hukum pidana" dapat pula disebut dengan istilah "politik hukum pidana". Dalam kepustakaan asing istilah "politik hukum pidana" ini sering dikenal dengan berbagai istilah, antara lain "penal policy", "criminal law policy" atau strafrechts politiek".
Pengertian kebijakan atau politik hukum pidana dapat dilihat dari politik hukum maupun dari politik kriminal. Menurut Sudarto, "Politik Hukum" adalah :

a. Usaha untuk mewujudkan peraturan-peraturan yang baik sesuai dengan keadaan dan situasi pada suatu saat. ${ }^{6}$

b. Kebijakan dari negara melalui badan-badan yang berwenang untuk menetapkan peraturanperaturan yang dikehendaki yang diperkirakan bisa digunakan untuk mengekspresikan apa yang terkadung dalam masyararakat dan untuk mencapai apa yang dicita-citakan. $^{7}$

Hak asasi manusia dalam konteks sistem peradilan pidana (criminal justice system) yang berada dalam kerangka jaringan sistem peradilan pidana yang mendayagunakan hukum

\footnotetext{
${ }^{6}$ Sudarto, Hukum dan Hukum Pidana, Bandung : Alumni, 1981, hal. 159.

${ }^{7}$ Sudarto, Hukum Pidana dan Perkembangan Masyarakat, Bandung: Sinar Baru, 1983, hal.20.
} 
pidana (hukum pidana materiil, hukum pidana formil dan hukum pelaksanaan pidana) kiranya tidak akan memperoleh gambaran menyeluruh dan sistemik, sehingga perlu dikaji secara utuh mencakup administrasi peradilan pidana (administration of criminal justice) yang memiliki daya jangkau lebih luas mulai dari kebijakan peradilan pidana (criminal justice policy), hak dan kewajiban serta penguasa dalam memperlakukan pelaku tindak pidana, saksi, dan korban. ${ }^{8}$

\section{Barda Nawawi Arief, Sistem} peradilan pidana pada hakikatnya identik dengan sistem penegakan hukum pidana. ${ }^{9}$ Penegakan hukum pidana pada dasarnya merupakan sistem kekuasaan atau kewenangan menegakkan hukum. ${ }^{10}$ Peneggakan hukum dalam bahasa inggris disebut

${ }^{8}$ Muladi, Hak Asasi Manusia Hakekat, Konsep dan Implikasinya dalam Perspektif Hukum dan Masyarakat, Bandung : Refika Aditama, 2015, hal 27.

${ }^{9}$ Barda Nawawi Arief, Kapita Selekta Hukum Pidana tentang Sistem Peradilan Pidana Terpadu, Semarang: Badan Penerbit UNDIP, 2006, hal.19.

${ }^{10}$ Ibid. dengan "law enforcement" dan menurut Black's Law Dictionary diartikan sebagai "The act of putting something such as a law into effect the execution of a law the carrying out of a mandate or command"11 sistem peradilan pidana dalam konteks kewenangan yang dimiliki oleh masing-masing lembaga penegakan hukum, dengan menyatakan bahwa sistem peradilah pidana pada hakikatnya merupakan "sistem kekuasaan menegakkan hukum pidana" atau "sistem kekuasaan kehakiman" dibidang hukum pidana, yang diwujudkan atau diimplementasikan dalam 4 (empat) sub-sitem yaitu :

1. Kekuasaan penyidikan (oleh badan/lembaga penyidik)

2. Kekuasaan penuntutan (oleh badan/lembaga penuntut umum)

3. Kekuasaan mengadili dan menjatuhkan putusan/pidana (oleh badan pengadilan)

11 Black, Henry Campbell, Black's Law Dictionary, Edisi VI. West Publishing, St. Paul Minesota, 1990. 
4. Kekuasaan pelaksanaan putusan pidana (oleh badan/aparat pelaksana/eksekusi)

Menurut Romli Atmasasmita, dengan mengutip pendapat dari Geoffrey Hazard Jr. dalam sistem peradilan pidana dikenal tiga bentuk pendekatan, yaitu pendekatan normatif, administratif dan sosial. ${ }^{12}$ Pendekatan normatif memandang keempat aparatur penegak hukum (kepolisian, kejaksaan, pengadilan, dan lembaga pemasyarakatan sebagai institusi pelaksanaan peraturan perundang-undangan yang berlaku, sehingga keempat aparatur tersebut merupakan bagian yang tidak terpisahkan dari sistem penegakan hukum semata-mata pendekatan administratif memandang keempat aparatur penegak hukum sebagai suatu organisaasi manajemen yang memiliki mekanisme kerja, baik hubungan yang bersifat horisontal maupun yang bersifat vertikal sesuai dengan struktur

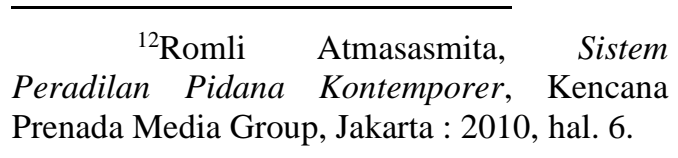

organisasi yang berlaku dalam organisasi tersebut, serta sistem yang digunakan adalah sistem administrasi. Pendekatan sosial yang memandang keempat aparatur penegak hukum merupakan bagian yang tidak terpisahkan dari suatu sistem sosial, sehingga masyarakat secara keseluruhan ikut bertanggung jawab atas keberhasilan atau ketidak berhasilan dari kelima aparatur penegak hukum tersebut dalam melaksanakan tugasnya. Sistem yang dipergunakan adalah sistem sosial ${ }^{13}$

Soerjono Soekanto mengatakan bahwa penegakan hukum adalah kegiatan menyerasikan hubungan nilainilai yang terjabarkan dalam kaidahkaidah mantap dan sikap tindak sebagai rangkaian penjabaran nilai tahap akhir, untuk menciptakan, memelihara dan mempertahankan perdamaian pergaulan hidup. Sementara itu, Muladi berpendapat bahwa penegakkan hukum merupakan usaha untuk menegakkan normanorma hukum dan sekaligus nilai-nilai 
yang ada di belakang norma tersebut. Dengan demikian, para penegak hukum harus memahami benar-benar spirit hukum (legal Spirit) yang mendasari peraturan hukum yang harus ditegakkan dan dalam hal ini akan berkaitan dengan berbagai dinamika yang terjadi dalam proses pembuatan perundang-undangan (law Making Process) ${ }^{14}$

Lebih lanjut, menurut Mardjono Reksodiputro, Sistem Peradilan Pidana memiliki tujuan sebagai berikut $:^{15}$

a. Mencegah masyarakat menjadi korban

b. Menyelesaikan kasus kejahatan yang terjadi sehingga masyarakat puas bahwa keadilan telah diteggakkan dan yang bersalah pidana

c. Mengusahakan agar mereka yang pernah melakukan

${ }^{14}$ Muladi, Hak Asasi Manusia, Politik dan Sistem Peradilan Pidana, Jakarta: Pusat Pelayanan Keadilan dan Pengabdian Hukum Universitas Indonesia, 2007, hal. 85.

15 Mardjono Reksodipuro, Hak Asasi Manusia Dalam Sistem Peradilan Pidana, Jakarta : Pusat Pelayanan Keadilan dan Pengabdian Hukum Universitas Indonesia, 2007, hal 85. kejahatan tidak menggulangi

lagi kejahatannya

Satjipto Raharjo, penegakan hukum adalah suatu proses untuk mewujudkan keinginan-keinginan hukum (yaitu pikiran-pikiran badan pembuat undang-undang yang dirumuskan dalam peraturan-peraturan hukum) menjadi kenyataan. ${ }^{16}$ Penegakan hukum sendiri harus diartikan dalam kerangka tiga konsep, yaitu sebagai berikut :

a. Konsep penegakan hukum yang besifat total (total enforcement concept) yang menuntut agar semua nilai yang ada di belakang norma hukum tersebut diteggakan tanpa terkecuali.

b. Konsep penegakan hukum yang bersifat penuh (full enforment concept) yang menyadari bahwa konsep total perlu dibatasi dengan hukum acara dan sebagainya demi

16 Satjipto Raharjo, Penegakan Hukum, Genta Publishing, Yogyakarta, 2009, hal. 24. 
perlindungan kepentingan

individual.

c. Konsep penegakkan hukum actual (actuan enforcement concept) yang muncul setelah diyakini adanya diskresi dalam penegakkan hukum karena keterbatasan-keterbatasan, baik yang berkaitan dengan saranaprasarana, kualitas sumber daya manusianya, kualitas perundang-undangannya dan kurangnya partisipasi masyarakat.

Berpijak kepada teori penegakan hukum Soerjono Soekanto, Faktorfaktor penegakkan hukum atau yang lebih dikenal dengan istilah law enforcement yaitu : ${ }^{17}$

a. Faktor hukumnya sendiri, yaitu peraturan perundang-undangan yang berlaku di Indonesia.

b. Faktor penegak hukum, yakni pihak-pihak yang membentuk maupun menerapkan hukum.

17 Soerjono Soekanto, Faktor-Faktor Yang Mempengaruhi Penegakan Hukum, Jakarta Rajawati Pers, 2016, hal. 21. c. Faktor sarana atau fasilitas yang mendukung penegakan hukum.

d. Faktor masyarakat, yakni lingkungan diaman hukum tersebut berlaku atau diterapkan.

e. Faktor kebudayaan, yakni sebagai hasil karya, cipta dan rasa yang didasarkan pada karsa manusia di dalam pergaulan hidup.

Korban bukan hanya dimaksudkan sebagai objek dari suatu tindak pidana, akan tetapi harus dipahami pula sebagai subjek yang perlu mendapatkan perlindungan secara social dan hukum, korban adalah mereka yang menderita jasmaniah dan rohaniah sebagai akibat dari tindakan orang lain yang mencari pemenuhan kepentingan diri sendiri atau orang lain yang bertentangan dengan kepentingan dan hak asasi pihak yang dirugikan. ${ }^{18}$ Mardjono

Reksodipuro mengemukakan beberapa alasan

18 Arif Gosita, Masalah Korban Kejahatan, Jakarta: Akademika Pressindo, 1993, hal. 188. 
mengapa perlindungan korban (kejahatan) harus dapat perhatian, yaitu : ${ }^{19}$

1. Sistem peradilan pidana dianggap terlalu memberikan perhatian pada permasalahan dan peran pelaku kejahatan (offender centered).

2. Terdapat potensi informasi dari korban untuk memperjelas dan melengkapi penafsiran tentang statistik kriminal melalui riset tentang korban dan harus dipahami bahwa korbanlah yang menggerakan mekanisme sistem peradilan pidana.

3. Semakin disadari bahwa selain korban kejahatan konvensional, tidak kurang pentingnya untuk memberikan perhatian kepada korban kejahatan nonkonvensional maupun korban penyalahgunaan kekuasaan.

Pada dasarnya kebijakan legislatif atau kebijakan perundang-undangan,

19 Fattah dalam Faroek Muhammad, Perlindungan Saksi dan Korban Berdasarkan KUHAP dan Undang-Undang Kepolisian, Bandung : 2004, hal. 1. secara fungsional dapat dilihat sebagai bagian dari perencanaan dan mekanisme penanggulangan kejahatan, bahkan dapat dikatakan sebagai langkah awal. ${ }^{20}$ Kebijakan atau upaya penanggulangan kejahatan pada hakikatnya merupakan bagian integral dari upaya perlindungan masyarakat (social defence) dan upaya mencapai kesejahteraan masyarakat (social welfare).

Dapat dikatakan, bahwa tujuan akhir atau tujuan utama dari politik kriminal ialah "perlindungan masyarakat untuk mencapai kesejahteraan masyarakat". Wajar apabila kebijakan atau politik hukum pidana juga merupakan bagian integral dari kebijakan atau politik social (social policy). Kebijakan social (sosial policy) dapat diartikan sebagai usaha yang rasional untuk mencapai kesejahteraan masyarakat dan sekaligus mencakup perlindungan masyarakat. Jadi di dalam pengertian

\footnotetext{
20 Romli Atmasasmita, Masalah Pengaturan Terorisme Dan Perpektif Indonesia, Jakarta: Badan Pembinaan Hukum Nasional Departemen Kehakiman dan HAM RI, 2002, Hal.3.
} 
"social policy" sekaligus tercakup di dalamnya "social welfare" dan social defence policy". ${ }^{21}$

Menurut Barda Nawawi Arief dan Muladi, kebijakan penanggulangan kejahatan yang dituangkan dalam peraturan perundang-undangan secara garis besar meliputi: ${ }^{22}$

a. Perencanaan atau kebijakan tentang perbuatan-perbuatan terlarang apa yang akan ditanggulangi karena dipadang membahayakan atau merugikan.

b. Perencanaan atau kebijakan tentang sanksi apa yang dapat dikenalkan terhadap pelaku perbuatan terlarang itu (baik berupa pidana atau tindakan) dan sistem penerapan.

c. Perencanaan atau kebijakan tentang prosedur atau mekanisme peradilan pidana

21 Barda Nawawi Arief, Kapita Selekta Hukum Pidana, Bandung: Aditya Bakti, 2002, hal 29.

${ }^{22}$ Barda Nawawi Arief dan Muladi, Bunga Rampai Kebijakan Hukum Pidana, Bandung: Alumni, 1992, hal. 158-159. dalam rangka proses penegakan hukum pidana.

Tidak mudah untuk menetapkan suatu perbuatan sebagai suatu tindak pidana artinya ada beberapa proses yang harus dilalui. Selain kajian yang mendalam mengenai perbuatan itu dari sudut kriminologi, maka harus dipertimbangkan pula beberapa hal yang perlu diperhatikan, yaitu tujuan hukum pidana itu sendiri, penetapan perbuatan yang tidak dikehendaki, perbandingan antara sarana dan hasil dan kemampuan badan penegak hukum. $^{23}$

Dalam rangka mencegah memerangi Terorisme, sejak jauh sebelum maraknya kejadian-kejadian yang digolongkan sebagai bentuk terorisme terjadi di dunia, masyarakat interenasional maupun regional serta berbagai Negara telah berusaha melakukan kebijakan criminal (criminal policy) disertai kriminalisasi secara sistematik dan komprehensif terhadap perbuatan yang dikategorikan

\footnotetext{
${ }^{23}$ Sudarto, Hukum Dan Hukum Pidana, Alumni, Bandung, 1986, Hal 32.
} 
sebagai terorisme. ${ }^{24}$ Namun demikian pengunaan hukum pidana atau perundang-undangan tentang pemberantasan terorisme dalam konstruksi criminal policy sebagai bagian social policy bukanlah satusatunya alat penanggulangan terorisme yang tunggal dan utama. Selain kebijakan kriminalisasi, usaha dan upaya memperbaiki kebijakan sosial dalam rangka memakmurkan masyarakat merupakan satu bagian lain dalam usaha mencegah kejahatan terorisme yang patut juga diperhatikan eksistensinya.

Romly Atmasasmita, menjelaskan bahwa dalam menghadapi terorisme di Indonesia harus mempertimbangkan latar belakang filosofis, sosiologis dan yuridis diperlukan suatu perangkat perundang-undangan yang memiliki visi dan misi serta terkandung prinsipprinsip hukum yang memadai sehingga dapat dijadikan penguat bagi landasan hukum bekerjanya sistem peradilan

\footnotetext{
24 Muladi, "Hakekat Terorisme dan Beberapa Prinsip Pengaturan dalam Kriminalisasi," tulisan dalam Jurnal Kriminologi Indonesia FISIP UI, vol 2 no III, Desember: 2002, Hal. 1.
}

pidana di mulai dari tingkat penyidikan sampai pada pemeriksaan di siding pengadilan. Undang-undang tersebut harus dapat mencerminkan nilai-nilai yang berkembang dan diperlukan masyarakat dan bangsa Indonesia baik pada masa kini maupun pada masa mendatang, dan sekaligus juga dapat mencerminkan nilai-nilai yang berlaku universal dan diakui masyarakat internasional.

Undang-undang Nomor 13 Tahun 2006 menganut pengertian korban dalam arti luas, yaitu seseorang yang mengalami penderitaan, tidak hanya secara fisik atau mental atau ekonomi saja, tetapi bisa juga kombinasi diantara ketiganya. Hal ini dapat dilihat pada Pasal 1 angka 1 UndangUndang Nomor 13 Tahun 2006 yang menyebutkan korban adalah seseorang yang mengalami penderitaan fisik, mental, dan/atau kerugian ekonomi yang diakibatkan oleh suatu tindak pidana.

Dalam pasal 5 ayat (2) disebutkan bahwa hak sebagaimana dimaksud pada ayat (1) diberikan kepada saksi 
dan/atau korban tindak pidana dalam kasus-kasus tertentu sesuai dengan keputusan Lembaga Perlindungan Sanksi dan Korban (LPSK). Penjelasan dari Pasal 5 ayat (2) Undang-Undang Nomor 13 Tahun 2006, tidak setiap saksi atau korban yang memberikan keterangan (kesaksian) dalam suatu proses peradilan pidana, secara otomatis memperoleh perlindungan. ${ }^{25}$

Korban bukan hanya dimaksudakan sebagai objek dari suatu tindak pidana, akan tetapi harus dipahami pula sebagai subjek yang perlu mendapatkan perlindungan hukum secara social dan hukum. Secara luas pengertian korban diartikan bukan hanya sekedar korban yang menderita langsung, akan tetapi korban tidak langsung pun juga mengalami penderitaan yang dapat diklarifikasikan sebagai korban. Yang dimaksud korban tidak langsung di sini seperti, isteri kehilangan suami, anak yang kehilangan bapak, orangtua yang kehilangan anaknya, dan lainnya.

25 Agus Takariawan, Perlindungan Saksi dan Korban, Bandung : Pustaka Reka Cipta, 2016, Hal 252.
Mardjono Reksodipuro dalam hal ini mengemukakan beberapa alasan mengapa perlindungan korban (kejahatan) harus mendapat perhatian, yaitu :

1. Sistem peradilan pidana dianggap terlalu memberikan perhatian pada permasalahan dan peran pelaku kejahatan (offender centered)

2. Terdapat potensi informasi dari korban untuk memperjelas dan melengkapi penafsiran tentang statistik criminal melalui riset tentang korban dan harus dipahami bahwa korbanlah yang menggerakkan mekanisme sistem peradilan pidana.

3. Semakin disadari bahwa selain korban kejahatan konvensioanal, tidak kurang pentingnya untuk memberikan perhatian kepada korban kejahatan non-konvensional maupun korban penyalahgunaan kekuasaan. 
Barda Nawawi Arief menyatakan bahwa pengertian perlindungan korban dapat dilihat dari dua makna, yaitu: ${ }^{26}$

a. Dapat diartikan sebagai "perlindungan hukum untuk tidak menjadi korban tindak pidana", (berarti perlindungan hak asasi manusia atau kepentingan hukum seseorang).

b. Dapat dartikan sebagai “ perlindungan untuk memperoleh jaminan/santunan hukum atas penderitaan/kerugian orang yang telah menjadi korban tindak pidana", (jadi identik dengan "penyantunan korban”). Bentuk santunan itu dapat berupa pemulihan namabaik (rehabilitasi), pemulihan keseimbangan batin (antara lain dengan pemanfaatan), pemberian ganti rugi (restitusi, kompensasi, jaminan/santunan

26 Arief, Barda Nawawi. Masalah Penegakan Hukum dan Kebijakan Hukum Pidana dalam Penanggulangan Kejahatan, Jakarta: Kencana Prenada Media Group, 2007. hal. 61. kesejahteraan sosial), dan sebagainya.

Perlindungan korban dapat diwujdukan dalam berbagai bentuk seperti pemberian retretusi, kompensasi, pelayanan medis dan bantuan hukum. Terhadap pengertian "perlindungan" yaitu bentuk pelayanan yang diberikan oleh aparat penegak hukum atau aparat keamanan untuk memberikan rasa aman baik fisik maupun mental kepada korban penganiayaan dari gangguan, ancaman, teror dan kekerasan dari pihak lain. ${ }^{27}$

Perlindungan korban kejahatan dapat dilihat dari beberapa teori, di antaranya sebagai berikut $:^{28}$

1. Teori Utilitas Teori ini menitik beratkan pada kemanfaatan yang terbesar dari jumlah yang terbesar.

2. Teori Tanggung Jawab Pada hakekatnya subjek hukum (orang maupun kelompok)

${ }^{27}$ R. Wiyono, Pengadilan Hak Asasi Manusia di Indonesia, Jakarta: Prenadamedia, 2015, hal. 78.

28 Didik M. Arif Mansur, Urgensi Perlindungan, Jakarta Raja Grafindo Persada, 2007 hal. 163. 
bertanggung jawab terhadap segala perbuatan hukum yang dilakukannya.

\section{Teori Ganti Kerugian Sebagai} perwujudan tanggung jawab karena kesalahannya terhadap orang lain pelaku dibebani kewajiban untuk memberikan ganti rugi.

Selama ini, berdasarkan sistem peradilan pidana Indonesia, ${ }^{105}$ kedudukan korban sebagai pihak yang mencari keadilan, selama ini terabaikan. Di sisi lain,

sistem peradilan pidana Indonesia lebih memberikan perhatian penuh terhadap pelaku tindak pidana. ${ }^{106}$ Adanya ketidak seimbangan dalam pengaturan mengenai pemenuhan hak, merupakan suatu bentuk ketidakadilan bagi korban. Padahal, korban merupakan pihak yang paling dirugikan dalam adanya tindak pidana tersebut. Korban hanya difungsikan sebagai sarana pembuktian. Hal tersebut menjadikan sistem peradilan pidana, baik dalam hal lembaga maupun pranata hukumnya lebih memberikan porsi lebih terhadap pelaku kejahatan, sehingga eksistensi korban tersubordinasikan dan bahkan tereliminasi sebagai risk secondary victimizations dalam sistem peradilan pidana. ${ }^{107}$

Adapun bentuk perlindungan atas kepentingan korban tindak pidana di Indonesia, menurut Muladi bahwa model sistem peradilan pidana yang dianut di Indonesia mengacu pada daad-dader strafrecht atau model keseimbangan kepetingan yang dipilih dari aliran neoklasik. Ditambahkan oleh Muladi, bahwa model tersebut disebut juga dengan model realistik yang memperhatikan kepentingan yang harus dilindungi oleh hukum pidana, yaitu kepentingan negara, kepentingan individu, kepentingan pelaku tindak pidana, dan kepentingan korban tindak pidana. ${ }^{29}$

Hak-hak korban tindak pidana terorisme di Indonesia, telah diatur dalam secara yuridis dalam UndangUndang Nomor 15 Tahun 2003

\footnotetext{
29 Muladi, Kapita Selekta Sistem Peradilan Pidana, (Semarang: UNDIP, 1995), hal. 5.
} 
tentang Penetapan Peraturan

Pemerintah Pengganti Undang-Undang Nomor 1 Tahun 2002 tentang Pemberantasan Tindak Pidana Terorisme Menjadi Undang-Undang dan Undang- Undang Nomor 13 Tahun 2006 tentang Perlindungan Saksi dan Korban, sebagaimana telah diubah dengan Undang-Undang Nomor 31 Tahun 2014 tentang Undang-Undang Perubahan Atas Undang-Undang Nomor 13 Tahun 2006 Tentang Perlindungan Saksi dan Korban.

Selain ketentuan mengenai perlindungan korban tindak pidana terorisme yang diatur dalam UU No. $15 / 2003$, terdapat pula UU PSK yang mengatur mengenai perlindungan korban tindak pidana. Pengaturan mengenai perlindungan saksi dan korban secara umum, terdapat dalam Pasal 5, Pasal 6, dan Pasal 7 UU PSK. Sebagaimana telah disinggung sebelumnya, bahwa dalam Pasal 5 UU PSK disebutkan beberapa hak saksi dan korban tindak pidana secara umum, seperti memperoleh perlindungan atas keamanan, pribadi, keluarga, dan harta bendanya, serta bebas dari ancaman yang berkenaan dengan kesaksian yang akan, sedang, atau telah diberikannya, dan lain sebagainya.

Kemudian, berdasarkan ketentuan dalam Pasal 6 UU PSK, dijelaskan tambahan bantuan yang diberikan pemerintah kepada korban tindak pidana khusus, salah satunya adalah korban tindak pidana terorisme. Adapun isi dari Pasal 6 UU PSK adalah :

\section{Pasal 6 ayat (1)}

Korban pelanggaran hak asasi manusia yang berat, Korban tindak pidana terorisme, Korban tindak pidana perdagangan orang, Korban tindak pidana penyiksaan, Korban tindak pidana kekerasan seksual, dan Korban penganiayaan berat, selain berhak sebagaimana dimaksud dalam Pasal 5, juga berhak mendapatkan:

a. Bantuan medis; dan

b. Bantuan rehabilitasi psikososial dan psikologis.

Namun sekali lagi, pengaturan 
dalam UU PSK mengenai hak untuk mendapatkan bantuan medis dan bantuan rehabilitasi psikososial dan psikologi belum diatur lebih lanjut, yang mana dapat menyebabkan ketidakjelasan dan ketidakpastian terhadap korban tindak pidana terorisme. Perlindungan hukum korban tindak pidana terorisme sebagai bagian dari perlindungan masyarakat dan tanggung jawab negara dapat diwujudkan dalam berbagai bentuk, seperti pemberian restitusi dan kompensasi, pelayanan medis, psikologi dan psikososial, serta bantuan hukum. Hal tersebut merupakan salah satu bentuk pelayanan negara kepada masyarakat, sebagaimana yang disampaikan oleh Satjipto Rahardjo, bahwa perlindungan hukum adalah memberikan pengayoman terhadap hak asasi manusia yang dirugikan orang lain dan perlindungan itu diberikan kepada masyarakat agar dapat menikmati semua hak- hak yang diberikan oleh hukum.

Secara normatif, UU No.
15/2003 dan UU PSK tahun 2014 dapat dikategorikan sebagai produk hukum yang mencoba memberikan perlindungan hukum kepada korban tindak pidana terorisme. Namun, tentu saja kedua substansi hukum tersebut masih terdapat kekurangankekurangan yang perlu diperbaiki, sebagaimana telah disebutkan sebelumnya. Berlandaskan atas kekurangan dan kelemahan perlindungan hak korban tindak pidana terorisme di Indonesia itulah, diharapkan rekomendasi model perlindungan hak korban tindak pidana terorisme ke depannya dapat digunakan dalam rangka memberikan perbaikan model perlindungan korban tindak pidana terorisme.

Berdasarkan pemaparan sebelumnya, bahwa ternyata pengaturan dan kondisi pemenuhan hak korban terorisme di Indonesia, masih jauh dari harapan, apabila merujuk pada sistem hukum yang diperkenalkan oleh Lawrance Friedman, diketehui bahwa struktur hukum dalam hal perlindungan korban 
tindak pidana terorisme di Indonesia hanya berpangku pada Lembaga Perlindungan Saksi dan Korban Republik Indonesia (LPSK). Adapun kewenangan LPSK hanya terbatas pada pemenuhan hak prosedural, hak pelayanan medis, dan hak mendapatkan pelayanan psikologis dan psikososial. Undang-Undang Nomor 15 Tahun 2003 dan UndangUndang LPSK yang mana mengatur mengenai hak serta perlindungan korban tindak pidana secara umum. Kemudian, secara khusus untuk tindak pidana tertentu, salah satunya korban tindak pidana terorisme ditambahkan beberapa hak khusus, yaitu hak mendapatkan pelayanan medis, hak untuk mendapatkan pelayanan psikososial dan psikologi.

Adapun dalam rangka
pemberian pelayanan medis,
psikososial dan psikologi, LPSK
sebagai lembaga yang bertanggung
jawab atas perlindungan korban tindak
pidana terorisme dapat melakukan
peningkatan kerjasama dan koordinasi
dengan institusi terkait. ${ }^{292}$ Sampai saat

ini LPSK telah bekerjasama dengan aparat penegak hukum lain, seperti kepolisian, kejaksaan, dan Badan Nasional Penanggulangan Terorisme (BNPT). Pasca berlakunya UU PSK tahun 2014, terlihat bahwa kerjasama dengan kepolisian serta kejaksaan sudah menunjukan perbaikan koordinasi, yang mana dapat diketahui dengan adanya Surat Edaran Jaksa Agung tentang pencantuman hak kompensasi dalam surat dakwaan yang telah mendapatkan penghitungan nilai dari LPSK. Namun, koordinasi LPSK dengan BNPT sebagai koordinator penanggulangan tindak pidana terorisme masih cukup jauh dari kata baik. Hal tersebut diketahui bahwa terjadi tumpang tindih kewenangan dalam memberikan perlindungan hak korban tindak pidana terorisme antara BNPT dan LPSK. ${ }^{293}$

Selain itu LPSK juga bekerjasama dengan rumah sakitrumah sakit di seluruh Indonesia, dalam rangka pemenuhan pelayanan medis. Kemudian, dalam rangka pelayanan psikososial, LPSK telah 
menjalin kerjasama dengan berbagai Pemerintah Daerah dan Kementerian untuk memberikan bantuan kepada korban tindak pidana terorisme. Namun di sisi lain, LPSK belum membangun kerjasama dengan lembaga swadaya masyarakat atau Non Government Organization (NGO). ${ }^{295}$ Padahal di beberapa kesempatan, NGO ini yang melakukan pendampingan psikososial dan psikologis terhadap kelompok-kelompok korban tindak pidana terorisme. Kerjasama berupa pertukaran informasi, bantuan hibah, dan berbagai macam bentuk kerjasama lainnya yang dapat dipertanggungjawabkan hasilnya tentu dapat mengurangi beban kerja LPSK dalam memberikan pelayanan psikososial dan psikologis bagi korban tindak pidana terorisme.

\section{Penutup}

Indonesia telah memiliki peraturan perundangan yang mengatur mengenai perlindungan dan hak korban tindak pidana terorisme, melalui UU No. 15/2003 dan UU PSK. Bahkan, pasca revisi UU PSK tahun 2014, terjadi banyak perubahan ke arah positif mengenai perlindungan hak korban terorisme. UU PSK memberikan amanat untuk memberikan tambahan bantuan yang diberikan pemerintah, yaitu bantuan medis, bantuan rehabilitasi psikososial, dan psikologis, serta jaminan mendapatkan hak kompensasi bagi korban. Namun, kedua peraturan perundangan tersebut telah memberikan perlindungan hak terhadap korban tindak pidana terorisme, namun masih terdapat beberapa kelemahan, sehingga penegakan perlindungan hak korban tindak pidana terorisme tidak dapat dilaksanakan dengan baik dan efektif. Pemerintah melalui rancangan perubahan UU No. 15/2003, UU PSK, RKUHAP, dan RKUHP harus lebih memperhatikan perkembangan politik hukum pidana yang berfokus pada perlindungan korban, khususnya korban tindak pidana terorisme ke depan. Hal tersebut dikarenakan pembahasan mengenai tindak pidana terorisme lebih terfokus pada pelaku 
(offender oriented), daripada korban (victim oriented). Padahal posisi korban tindak pidana terorisme merupakan pihak yang paling dirugikan dan mendapatkan beban yang berat akibat terjadinya tindak pidana terorisme.

\section{Daftar Pustaka}

Arief, B. N. (2010). Bahan Bacaan Politik Hukum Pidana. Semarang: Pasca Sarjana Universitas Pattimura.

Arief, B. N. (2010). Beberapa Aspek Pengembagan Ilmu Hukum Pidana (Menyongsong Generasi Baru Hukum Pidana). Semarang: Universitas Diponegoro.

Arief, B. N. (2011). Bunga Rampai Kebijakan Hukum-Perkembagan Penyusunan Konsep KUHP Baru. Jakarta: Prananda Media Group.

Arief, B. N. (2006). Kapita Selekta Hukum Pidana tentang Sistem Peradilan Pidana Terpadu. Semarang: Badan Penerbit UNDIP.

Arif, B. N. (2007). Masalah Penegakan Hukum dan Kebijakan Hukum Pidana dalam Penanggulangan Kejahatan. Jakarta: Kencana Prenada Media Group.

Atmasasmita, R. (2010). Sistem Peradilan Pidana Kontemporer. Jakarta: Kencana Prenada Media Group.

Atmasasmta, R. (2002). Masalah Pengaturan Terorisme Dan Perpektif Indonesia. Jakarta: Badan Pembinaan Hukum Nasional Departemen Kehakiman dan HAM RI.

Black, H. C. (1990). Black's Law Dictionary. St. Paul Minesota: Edisi VI. West Publishing.

Mansur, D. M. (2017). Urgensi Perlindungan. Jakarta: Raja Grafindo Persada.

Muhammad, F. (2004). Perlindungan Saksi dan Korban Berdasarkan KUHAP dan Undang-Undang Kepolisian. Bandung. 
Muladi. (2015). Hak Asasi Manusia Hakekat, Konsep dan Implikasinya dalam Perspektif Hukum dan Masyarakat. Bandung: Refika Aditama.

Muladi. (2007). Hak Asasi Manusia, Politik dan Sistem Peradilan Pidana, Jakarta Pusat Pelayanan Keadilan dan Pengabdian Hukum. Jakarta: Universitas Indonesia.

Muladi. (1995). Kapita Selekta Sistem Peradilan Pidana. Semarang: UNDIP.

Nitibaskara, T. R. (2001). Tegakan Hukum Gunakan Hukum. Jakarta: Gramedia.

Raharjo, S. (2000). IlmuHukum. Jakarta: PT.Citra Aditya Bakti.

Raharjo, S. (2009). Penegakan Hukum. Yogyakarta: Genta Publishing.I

Reksodipuro, M. (2007). Hak Asasi Manusia Dalam Sistem Peradilan Pidana. Jakarta: Pusat Pelayanan Keadilan dan Pengabdian Hukum Universitas Indonesia.

Soekanto, S. (2016). Faktor-Faktor Yang Mempengaruhi Penegakan Hukum. Jakarta: PT Raja Grafindo Persada.

Sudarto. (1981). Hukum dan Hukum Pidana. Bandung: Alumni.

Sudarto. (1981). Kapita Selekta Hukum Pidana. Bandung: Alumni.

Takariawan, A. (2016). Perlindungan Saksi dan Korban. Bandung: Pustaka Reka Cipta.

Wiyono, R. (2015). Pengadilan Hak Asasi Manusia di Indonesia,. Jakarta: Prenadamedia,.

\section{Perundang-Undagan}

Undang-Undang Nomor 31 Tahun 2014 tentang Perunahan Atas Undang-Undang Nomor 13 Tahun 2006 Tentang Perlindungan Saksi dan Korban.

Undang-Undang Nomor 5 Tahun 2018 tentang Perubahan Atas Undang-Undang Nomor 15 Tahun 2003 Tentang Penetapan Peraturan Pemerintah Pengganti Undang-Undang Nomor 1 Tahun 2002 Tentang Pemberantasan Tindak Pidana Terorisme. 


\section{Sumber Lainnya}

Hasil Wawancara Penulis dengan Susilaningtias, Wakil Ketua LPSK RI, pada tanggal 21 Januari 2020 bertempat di LPSK.

Hasil Seminar Hukum Nasional II tentang Hukum Acara Pidana dan Hak-Hak Asasi Manusia, Semarang 28 Februari 1968, Barda Nawawi Arief, 2011, Kumpulan Hasil Seminar Hukum Nasional, Semarang, BP UNDIP.

Muladi, "Hakekat Terorisme dan Beberapa Prinsip Pengaturan dalam Kriminalisasi," tulisan dalam Jurnal Kriminologi Indonesia FISIP UI, vol 2 no III, Desember: 2002.

Muhammad Alfath, "Korban Sebagai Dampak dari Tindak Pidana Terorisme : Yang Anonim dan Terlupakan”, Jurnal Kriminologi Indonesia Vol. II, Agustus 2009. 